Article

\title{
Recovering Metals from Aqueous Solutions by Biosorption onto Hydrolyzed Olive Cake
}

\author{
Rafael Fernández-González, María Ángeles Martín-Lara *®D, Gabriel Blázquez $\mathbb{D}$, Antonio Pérez \\ and Mónica Calero
}

Chemical Engineering Department, Faculty of Sciences, University of Granada, 18071 Granada, Spain; rafafernandezgonzalez@outlook.es (R.F.-G.); gblazque@ugr.es (G.B.); aperezm@ugr.es (A.P.); mcaleroh@ugr.es (M.C.)

* Correspondence: marianml@ugr.es; Tel.: +34-958-240-445

Received: 30 October 2019; Accepted: 26 November 2019; Published: 28 November 2019

\begin{abstract}
Olive cake obtained as a by-product from the olive oil industry has been evaluated as biosorbent of heavy metals from aqueous solutions in batch and continuous systems (fixed-bed columns). First, a complete study of effect of hydrothermal treatment with water on biosorption capacity of resulting solid was performed. Results showed that the values of biosorption capacity increased when the particle size of material decreased and the temperature of treatment increased. Then, hydrolyzed olive cake was treated by common chemicals (hot water, nitric acid, and sodium hydroxide) and the impact of chemical treatment was analyzed. The results were well reproduced by Langmuir and Freundlich isotherm models, getting maximum experimental biosorption capacities that changed between $42.34 \mathrm{mg} / \mathrm{g}$ obtained for the solid material modified by $\mathrm{NaOH}$ and $14.27 \mathrm{mg} / \mathrm{g}$ obtained for the solid material modified by nitric acid. Finally, laboratory tests in fixed-bed columns were performed with four different heavy metals and at three different inlet concentrations. The biosorption capacity increased from $2.83 \mathrm{mg} / \mathrm{g}(\mathrm{Cr}), 4.51 \mathrm{mg} / \mathrm{g}(\mathrm{Cu}), 12.30 \mathrm{mg} / \mathrm{g}(\mathrm{Pb})$, and $4.10 \mathrm{mg} / \mathrm{g}$ (Zn) to $3.08 \mathrm{mg} / \mathrm{g}(\mathrm{Cr}), 5.17 \mathrm{mg} / \mathrm{g}(\mathrm{Cu}), 13.21 \mathrm{mg} / \mathrm{g}(\mathrm{Pb})$, and $5.51 \mathrm{mg} / \mathrm{g}(\mathrm{Zn})$ when the concentration of metal ions increased, from $50 \mathrm{mg} / \mathrm{L}$ to $200 \mathrm{mg} / \mathrm{L}$, respectively. Also, the experimental data obtained was successfully correlated with the Thomas, Yoon-Nelson, and dose-response models.
\end{abstract}

Keywords: biosorption; heavy metals; hydrothermal treatment; olive cake; wastewater treatment

\section{Introduction}

The continuous historical expansion of olive cultivation has marked the landscape, economy, and culture of Spain. Olive oil is especially important in Andalusia region. In the 2018/2019 campaign, global olive oil production is expected to exceed 3 million tons. In Spain, an increase in olive oil production is estimated to be $23.3 \%$ compared to last year. Andalusia will be the main producing region, with production forecasts of $86 \%$ of all olive oil nationwide and $44 \%$ globally. In addition, the area of olive for mill has experimented a progressive increase in recent years (93,600 ha in 10 years), currently exceeding 1.5 million hectares [1].

Although the main product derived from the olive grove is olives and its oily juice, it is clear that the agricultural management of the crop leads to the production of significant quantities of pruning. On the other hand, the processing of olives to produce olive oil in mills generates large by-products such as wet olive pomace that is generally intended for different uses. The technique most used includes (1) drying, (2) extraction of waste oil in extractors that use hexane (with or without prior olive stone separation), and finally, (3) combustion of the oil-free olive pomace (called olive cake) for energy purposes or (4) composting. 
Recently, some investigations have been performed to show new uses for olive cake. For example, Chebaibi et al. [2], Dorbane et al. [3], Ferrer et al. [4], Marcos et al. [5], and Symeou et al. [6] studied the use of olive cake as animal feed. Particularly, Symeou et al. [6] demonstrated desirable changes in ovine milk lipids. Also, Pasten et al. [7], Khalili and Dinani [8], and Mojerlou and Elhamirad [9] showed the potential of olive cake as source of high-value products (phenolic compounds). Similarly, Sandouqa et al. [10] generated a good catalyst from olive cake for biodiesel production. Others authors have proved olive cake as biosorbent of dyes, metals, and other pollutants such as diclofenac, ibuprofen, and triclosan [11-16]. In particular, Fernández-González et al. [12,13] demonstrated the possibility of the use of olive cake in acid mining effluents and zinc electroplating wastewater treatments. In addition, some other solid wastes have been recently applied for the removal of heavy metals from aqueous solutions or real industrial wastewaters. For example, Castro et al. $[17,18]$ investigated sugar beet pulp as adsorbent material for the removal of heavy metal ions from an electroplating industry and an abandoned sulfide mine. Other researchers analyzed the bark of Platanus orientalis as biosorbent to remove chromium and nickel from a nickel-chromium plating wastewater [19]. Other latest examples of solid waste used for the removal of some heavy metals from aqueous solution are soy waste biomass, a low-cost waste resulted from oil extraction [20] or hemp, an annual high-yielding industrial crop [21]. Although most of the biosorbents are made from waste from the industry or forestry and agricultural solid waste, the literature also reports the use of bacteria, algae, or fungi for the removal of toxic metals removal from wastewaters [22,23].

On the other hand, liquid hot-water treatment of different types of residual biomasses has increased attention of scientists since this hydrothermal treatment has a high potential to provide interesting compounds for industrial purposes and solid materials with applications as fuels or adsorbents following a sequential process integrated in the biorefining concept [14,24-28]. Primarily, researchers were focusing mainly on the operating conditions at elevated temperature and pressure [29]. In this work, very soft operational conditions to decrease energy consumption and favor exploitation of the residual material used as feedstock were studied.

The objective of this work was to provide knowledge about the recovering of metals from aqueous solutions by solid materials resulting from hydrothermal treatment with water, at very soft operational conditions, of olive cake. First, a statistical optimization to determine the optimum preparation conditions of hydrolyzed olive cake was performed. The effect of temperature and particle size over the biosorption behavior of the hydrolyzed materials was studied. Then, the biosorption capacity of the solid material when was exposed to different concentrations of chromium, copper, lead, and zinc in solution was studied. As far as we know, only works of Fernández-González et al. [12,13] have deeply analyzed the behavior of hydrolyzed olive cake as biosorbent of heavy metals from liquid effluents. However, these publications have not investigated the impact of hydrothermal treatment on biosorption properties of resulting materials. Therefore, the authors believe that this work can increase knowledge about the issue of removal of heavy metals from aqueous solutions by olive-oil by-products and waste.

\section{Materials and Methods}

\subsection{Material}

Olive cake was provided by an industrial plant that produces olive oil placed in Linares-Baeza (Jaén, Spain). The olive cake was first milled in an IKA mill, model MF10, and separated manually in different size fractions using CISA test sieves. Then, a solid of a fixed particle size was subjected to a hydrothermal treatment with water at different low temperatures for 1 hour to remove water-soluble compounds that interfere with the biosorption process. Also, the liquid fraction obtained may be valorized extracting compounds of interest include sugars, polyols, or polyphenols [20]. Later, the solid-liquid suspension was filtrated and the solid resulting from each test was dried and stored until its use in biosorption tests. Figure 1 shows the outline process chart, which gives an overall view of the process followed in this work. 


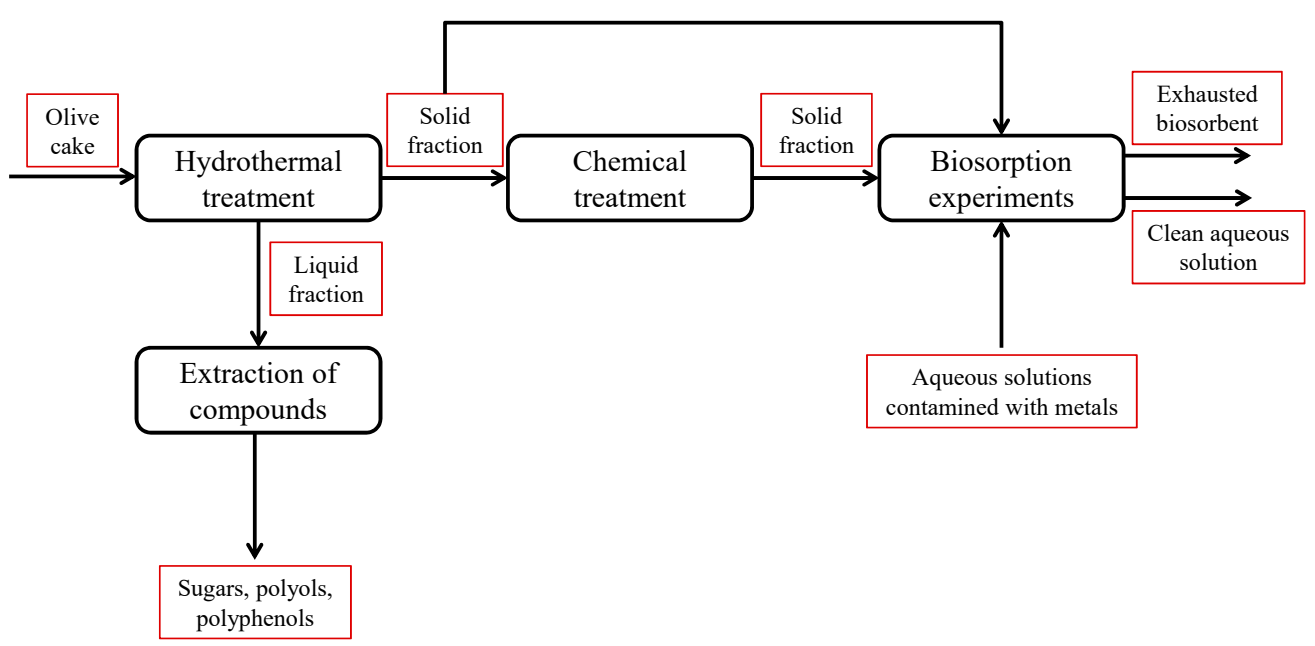

Figure 1. Overall view of the process followed in this work.

\subsection{Hydrothermal Treatment of Material and Preliminarily Biosorption Tests}

To analyze the impact of operational conditions during hydrothermal treatment on biosorption properties of solids, a design of experiments was carried out in which the operating variables that most affected the hydrolysis process were varied: Temperature and particle size. Accordingly, three temperatures $\left(30,50\right.$, and $\left.70{ }^{\circ} \mathrm{C}\right)$ and three particle sizes $(0.42 \mathrm{~mm}, 0.96 \mathrm{~mm}$, and $1.5 \mathrm{~mm})$ were chosen.

In this study, lead was selected as adsorbate, since it is one of those considered as most polluting for the environment and, in addition, the authors already have extensive knowledge of the behavior of this heavy metal in biosorption tests in aqueous media, in both batch and fixed-bed systems [29-35].

The first series of biosorption experiments were carried out in batch in $100 \mathrm{~mL}$ glass flasks that were shaken for a contact time of $2 \mathrm{~h}$ (sufficient for biosorption equilibrium) at room temperature. The following other operational conditions were chosen: Natural $\mathrm{pH}$ of solution (it was measured and in all cases was between 4.5 and 5), solid-liquid ratio of $5 \mathrm{~g} / \mathrm{L}$, lead concentrations of 25, 50, 100, 200, and $400 \mathrm{mg} / \mathrm{L}$.

Initially, a lead stock solution $(1000 \mathrm{mg} / \mathrm{L})$ was prepared using distilled water and lead (II) nitrate ACS reagent in solid form (assay $>99 \%$ ) provided by Sigma Aldrich, which was subsequently diluted for the experiments.

The residual concentration of lead after biosorption was measured with an Atomic Absorption Spectrometer (Perkin-Elmer, model AAnalyst 200).

The lead removal (expressed as percentage, \%) and the biosorption capacity, $q_{e}$ (expressed as the amount of lead removal from solution per solid mass, in $\mathrm{mg} / \mathrm{g}$ ) were calculated using Equations (1) and (2), respectively.

$$
\begin{gathered}
\text { \% removal }=\frac{C_{i}-C_{e}}{C_{i}} \cdot 100, \\
q_{e}=\frac{\left(C_{i}-C_{e}\right)}{m} \cdot V,
\end{gathered}
$$

where $C_{i}$ and $C_{e}$ are the initial and equilibrium lead concentrations (in $\mathrm{mg} / \mathrm{L}$ ), $\mathrm{m}$ is the mass of solid (in $\mathrm{g}$ ), and $V$ is the volume of the solution (in $\mathrm{L}$ ).

All tests were performed in duplicate and the average values were used in biosorption calculations.

\subsection{Biosorption Behavior of Solid Biosorbent}

\subsubsection{Batch Biosorption Experiments}

Once the better solid was chosen (according to results obtained in Section 2.2) and in order to improve the biosorption behavior of the solids, the hydrolyzed materials were also subjected to a 
chemical treatment with different chemical agents (hot water, nitric acid, and sodium hydroxide). These activations were carried out in a glass reactor whose temperature could be set using a controlled water flow through its jacket. Hot water and aqueous solutions of $1 \mathrm{M} \mathrm{NaOH}$ and $\mathrm{HNO}_{3}$ were prepared and put in contact with hydrolyzed solid in a dose of $10 \mathrm{~g} / \mathrm{L}$. The mixture was stirred for $24 \mathrm{~h}$ at $90^{\circ} \mathrm{C}$ and then the remaining solid was filtered using a vacuum pump. Finally, the filtered solid was rinsed with water 5 times, keeping the original dose of $10 \mathrm{~g} / \mathrm{L}$, dried in the oven, and left to achieve its moisture equilibrium content (sample reached a water content equilibrium with its environment and is no longer gaining or losing moisture). The value of moisture content was determined as approximately 4.51\% in work of Fernández-González et al. [12].

A new series of batch experiments was performed with lead solutions prepared in the laboratory of different initial concentrations. The experimental installation and operational conditions used in this series of biosorption experiments was the same of that described in Section 2.2.

\subsubsection{Continuous Biosorption Experiments in Fixed-Bed Columns}

Pyrex-glass fixed-bed columns were used in biosorption experiments in a laboratory scale. The columns had $1.5 \mathrm{~cm}$ internal diameter and $23 \mathrm{~cm}$ length and were packed with $18 \mathrm{~g}$ of hydrolyzed olive cake. The heavy metal solution, prepared at three different concentrations of 50, 100, and $200 \mathrm{mg} / \mathrm{L}$, was distributed through the packed bed in up-flow and at a constant flow rate of $4 \mathrm{~mL} / \mathrm{min}$. A peristaltic pump (D-21V model) was using to pump solution into the column. Every $15 \mathrm{~min}$, a sample of the effluent was collected and analyzed using a PerkinElmer (AAnalyst 200) atomic absorption spectrometer.

Four different heavy metals were studied: Chromium, copper, lead, and zinc, in order to compare behavior with results of Fernández-Gonzalez et al. [12] who previously studied biosorption of these metals by hydrolyzed olive cake in batch systems.

\subsection{Mathematical Background}

\subsubsection{Batch Biosorption Experiments: Equilibrium Models}

A suitable interpretation of biosorption isotherms is important for the effective design of biosorption system. Below, three of the most important isotherm models are described and applied in the work.

The mathematic expression of the Langmuir isotherm model is presented in Equation (3) [36]:

$$
q_{e}=\frac{b q_{m} C_{e}}{1+b C_{e}}
$$

where $q_{m}$ is the maximum biosorption capacity $(\mathrm{mg} / \mathrm{g})$ and $\mathrm{b}$ is the Langmuir constant that is related to the affinity of binding sites and is related to the energy of sorption $(\mathrm{L} / \mathrm{mg})$.

On the other hand, the Freundlich model [37] assumes an heterogeneous adsorbent's surface with different biosorption sites in which the energy varies as a function of the surface coverage. The model can be expressed as [37]:

$$
q_{e}=K_{F} C_{e}^{1 / n}
$$

The Sips model [38] is a three-parameter model that involves the characteristics of both the Langmuir and Freundlich models. The model is suitable for predicting biosorption on heterogeneous surfaces and can be expressed as:

$$
q_{e}=\frac{q_{m} b C_{e}^{1 / n}}{1+b C_{e}^{1 / n}}
$$

where $b$ is the equilibrium Sips constant $(\mathrm{L} / \mathrm{mg})^{1 / \mathrm{n}}$ and $\mathrm{n}$ is the heterogeneity factor. This isotherm is very flexible since at low $C_{e}$ values it is reduced to the Freundlich isotherm, for $\mathrm{n}$ equal to 1 is converted to the Langmuir isotherm and for $n=0$ or low concentrations and $n=1$ is transformed to Henry's law. 


\subsubsection{Continuous Biosorption Experiments in Fixed-Bed Columns: Breakthrough Curves Analysis}

Breakthrough curve was used to evaluate the dynamic behavior for biosorption process in the fixed-bed columns. This curve plots the normalized (ratio of effluent, $\mathrm{C}$ to inlet metal concentration, $C_{i}$ ) with contact time, $t$. The curve has three characteristic time values: The breakthrough time, $t_{b}$, is the time when the effluent concentration reaches its maximum permissible concentration (legal limit); exhaustion or saturation time, $t_{e x}$, is the time at which the effluent concentration reaches about $95 \%$ of the inlet concentration; $t_{50}$ is the time which the effluent concentration reaches about $50 \%$ of the inlet concentration. The characteristic parameters of the biosorption curves are described in Table 1. Also, three traditional models (Thomas, Yoon-Nelson, and dose-response), were used to fit the breakthrough curves.

Table 1. Characteristic parameters of breakthrough curves.

\begin{tabular}{|c|c|}
\hline Equation & Parameters \\
\hline$V_{e f f}=Q t_{\text {total }}$ & $\begin{array}{c}V_{\text {eff: }} \text { total volume of effluent, } \mathrm{mL} \\
t_{\text {total }}: \text { total operation time (until exhaustion), min } \\
Q: \text { volumetric feed flow rate, } \mathrm{mL} \cdot \mathrm{min}^{-1}\end{array}$ \\
\hline$q_{\text {total }}=\frac{Q}{1000} \int_{0}^{t} C_{R} d t$ & $\begin{array}{l}q_{\text {total }}: \text { total amount of metal ions adsorbed, } \mathrm{mg} \\
C_{R}: \text { adsorbed metal ion concentration, } \mathrm{mg} \cdot \mathrm{L}^{-1}\end{array}$ \\
\hline$m_{\text {total }}=\frac{C_{i} Q t_{\text {total }}}{1000}$ & $m_{\text {total }}:$ total amount of metal ion passed down through the column, mg \\
\hline$R=\frac{q_{\text {total }}}{m_{\text {total }}} 100$ & $R:$ total metal removal, \% \\
\hline$q_{e}=\frac{q_{\text {total }}}{m}$ & $\begin{array}{c}q_{e}: \text { biosorption capacity at equilibrium, } \mathrm{mg} \cdot \mathrm{g}^{-1} \\
m \text { : adsorbent mass used in the column, } \mathrm{g}\end{array}$ \\
\hline$C_{e}=\frac{m_{\text {total }}-q_{\text {total }}}{V_{\text {eff }}} 1000$ & $C_{e}:$ concentration of metal that remains in solution at equilibrium, $\mathrm{mg} \cdot \mathrm{L}^{-1}$ \\
\hline
\end{tabular}

\section{Results}

\subsection{Hydrothermal Treatment of Material}

Figure 2 shows the lead removal (expressed as percentage) of solids obtained from all hydrothermal treatments. A high value in lead removal was observed at low initial lead concentrations. As initial lead concentration increased, the lead removal was reduced (compare for example Figure 2a,e). This influence of initial metal concentration on percentage removal was previously described by other authors. For example, Akpomie et al. [39] analyzed the sorption of heavy metals by a low-cost montmorillonite and found a decrease from $64.8 \%$ to $37.63 \%$ and from $54.8 \%$ to $30.57 \%$ for nickel and manganese ions, respectively, when initial metal concentration changed from 100 to $300 \mathrm{mg} / \mathrm{L}$. Also, González-Bermúdez et al. [40] investigated the biosorption of chromium (VI) from the aqueous solutions by the brown seaweed Sargassum muticum and published a negative effect of initial metal concentration on removal efficiency. It is due to the fact that all sorbent materials have a determinate number of binding sites and at higher concentrations, the available sites become fewer because most of them are already occupied.

With respect to influence of particle size, in general, lead removal of solids improved by decreasing particle size. Pimol et al. [41] found a considerable increase of dyes biosorption by dried Seagrape (Caulerpa lentillifera) when lowest particle sizes were used. A reduction of biosorbent particle size provided more active sites for biosorption due to the increase of the specific surface area. Also, Hernáinz et al. [42] showed that the percentage removed of lead decreased when the particle size of olive tree pruning and olive stone was increased. 
a) Initial lead concentration: $25 \mathrm{mg} / \mathrm{L}$

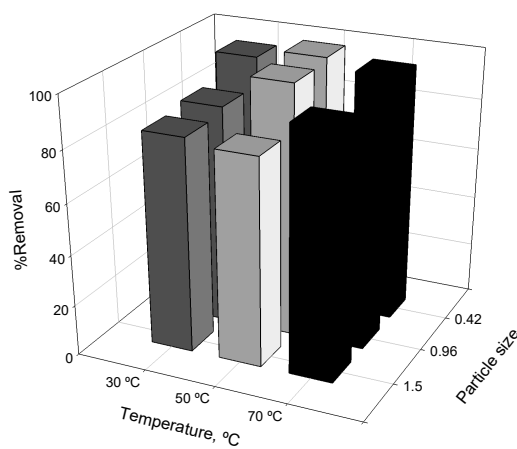

c) Initial lead concentration: $100 \mathrm{mg} / \mathrm{L}$

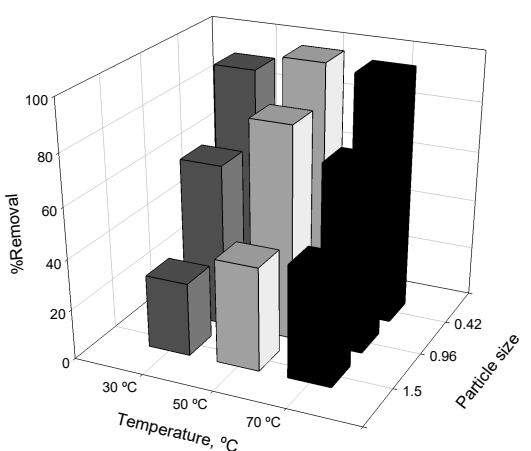

b) Initial lead concentration: $50 \mathrm{mg} / \mathrm{L}$

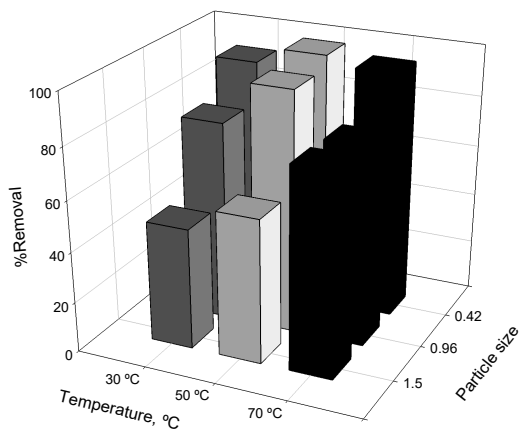

d) Initial lead concentration: $200 \mathrm{mg} / \mathrm{L}$

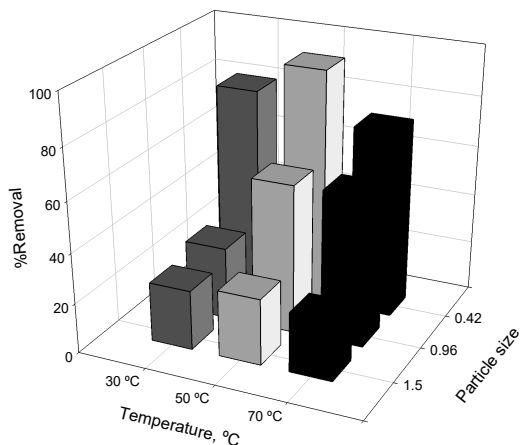

e) Initial lead concentration: 400 mg/L

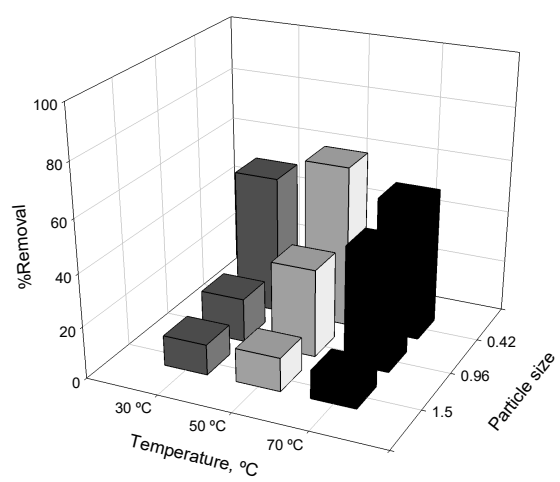

Figure 2. Lead removal (\%) versus temperature and particle size of material for different initial lead concentrations. (a) Initial lead concentration of $25 \mathrm{mg} / \mathrm{L}$; (b) Initial lead concentration of $50 \mathrm{mg} / \mathrm{L}$; (c) Initial lead concentration of $100 \mathrm{mg} / \mathrm{L}$; (d) Initial lead concentration of $200 \mathrm{mg} / \mathrm{L}$; (e) Initial lead concentration of $400 \mathrm{mg} / \mathrm{L}$.

Finally, the effect of temperature was not clear. For example, at an initial lead concentration of $50 \mathrm{mg} / \mathrm{L}$ and for a high particle size, an increase of temperature showed an increase of metal removal. However, if medium or low particle sizes are observed, the increase of temperature from $50{ }^{\circ} \mathrm{C}$ to $70{ }^{\circ} \mathrm{C}$ worsens the lead removal values. This is also observed for an initial lead concentration of $25 \mathrm{mg} / \mathrm{L}$, $100 \mathrm{mg} / \mathrm{L}$, or $200 \mathrm{mg} / \mathrm{L}$.

For a better explanation of the results obtained, Figure 3 shows the values of the maximum equilibrium biosorption capacity, $q_{e}$ (obtained for the higher concentration studied, $400 \mathrm{mg} / \mathrm{L}$ ) versus temperature and particle size. Again, the results show the influence of temperature and particle size on the biosorption but now analyzed by means of equilibrium biosorption capacity. The lowest $q_{e}$ values 
were obtained for the lowest temperature and the highest particle size. As the particle size decreased and the temperature increased, in general, the values of $q_{e}$ increased, and the highest values were found with the smallest particle size and temperatures of $50{ }^{\circ} \mathrm{C}\left(q_{e}=54.46 \mathrm{mg} / \mathrm{g}\right)$ and $70{ }^{\circ} \mathrm{C}\left(q_{e}=46.32 \mathrm{mg} / \mathrm{g}\right)$.

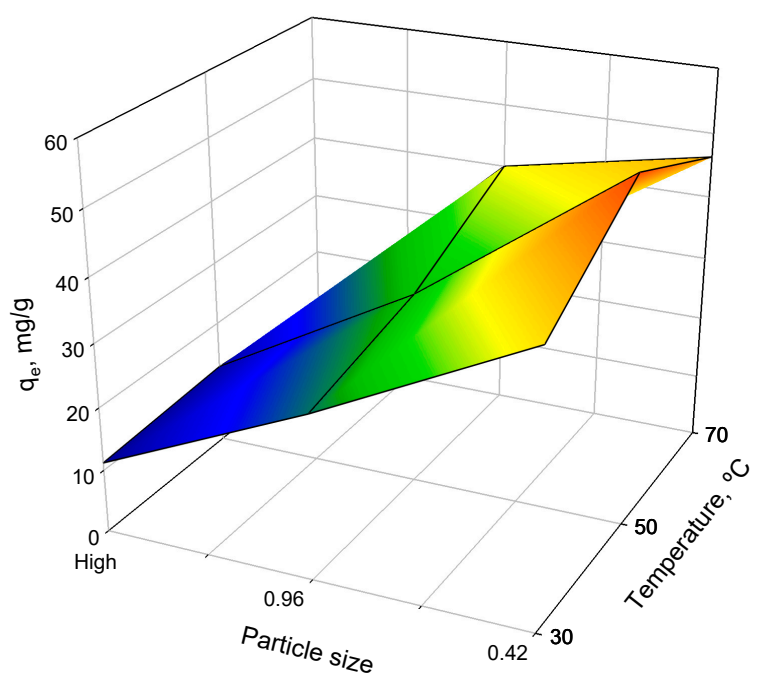

Figure 3. Maximum equilibrium biosorption capacity versus temperature and particle size of material for an initial lead concentration of $400 \mathrm{mg} / \mathrm{L}$.

Therefore, taking into account these results, a particle size lower than $0.96 \mathrm{~mm}$ was chosen for the rest of the tests (all solid with a particle size smaller than the intermediate size). The biosorption capacity also improved slightly as the temperature of the hydrothermal treatment increased. Nevertheless, involving high temperatures means an increase in energy costs in the real-scale application. At first sight, it is believed that the best option would perform the hydrothermal treatment at $30^{\circ} \mathrm{C}$. This theory was reinforced since, considering the data obtained from the liquid fraction resulting from hydrothermal treatment, the best solid was that resulting from hydrothermal treatment of olive cake with an intermediate particle size and performed at $30^{\circ} \mathrm{C}$ [27].

\subsection{Batch Equilibrium Biosorption Experiments}

In this section, results of biosorption equilibrium of untreated hydrolyzed olive cake (OC-untreated) and hydrolyzed olive cake treated by common chemicals $\left(\mathrm{OC}-\mathrm{H}_{2} \mathrm{O}, \mathrm{OC}-\mathrm{HNO}_{3}\right.$ and $\left.\mathrm{OC}-\mathrm{NaOH}\right)$ are presented.

Figure 4 shows the biosorption isotherms obtained for the removal of lead by different prepared materials. Also, Table 2 shows the characteristic parameters of Langmuir, Freundlich, and Sips models and the experimental biosorption capacity, $q_{e, e x p}$. The results for the experimental biosorption capacity changed between the value of $42.34 \mathrm{mg} / \mathrm{g}$ obtained for the $\mathrm{OC}-\mathrm{NaOH}$ and the value of $14.27 \mathrm{mg} / \mathrm{g}$ obtained for the $\mathrm{OC}-\mathrm{HNO}_{3}$. Therefore, in general, the best results are obtained with $\mathrm{NaOH}$ treatment. However, it should be taken into account that, during the treatment, a part of the solid mass is lost. As a result, Table 2 also shows the value of maximum biosorption capacity corrected, taking into account the mass loss during treatment, $q_{m, c o r}$. 


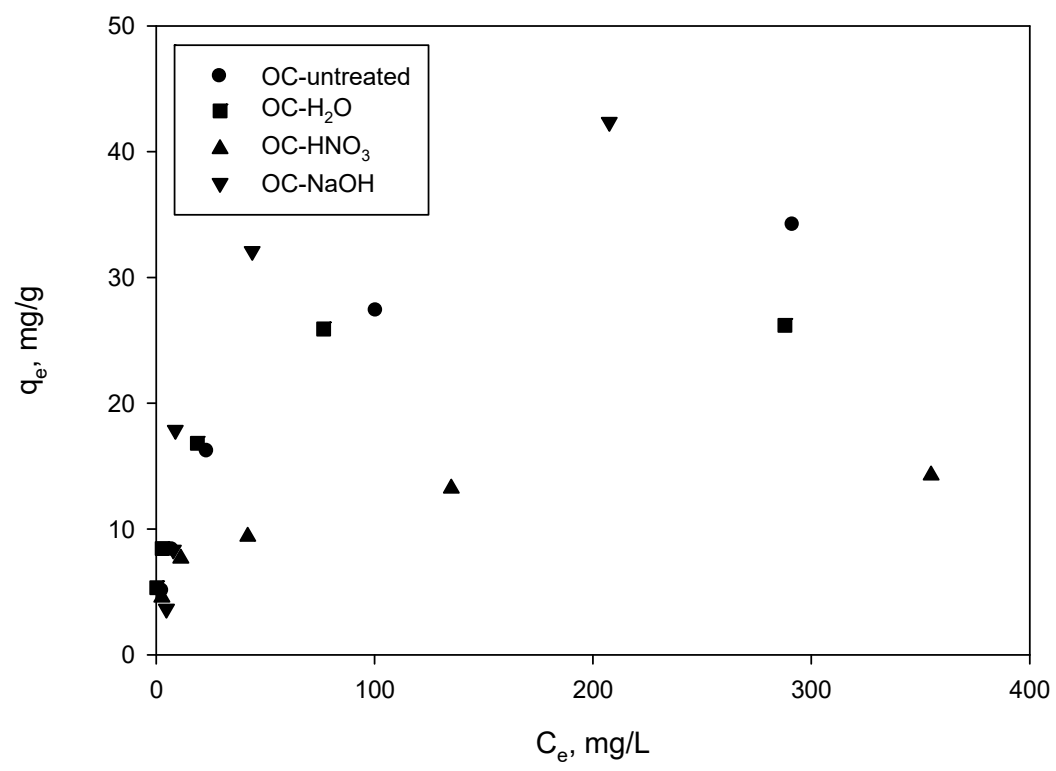

Figure 4. Lead equilibrium isotherms for different obtained materials (hydrolyzed olive cake, OC-untreated; hydrolyzed olive cake chemically treated by $\mathrm{H}_{2} \mathrm{O}, \mathrm{OC}-\mathrm{H}_{2} \mathrm{O}$; hydrolyzed olive cake chemically treated by $\mathrm{HNO}_{3}, \mathrm{OC}-\mathrm{HNO}_{3}$; hydrolyzed olive cake chemically treated by $\mathrm{NaOH}, \mathrm{OC}-\mathrm{NaOH}$ ).

Table 2. Langmuir and Freundlich isotherm parameters for lead biosorption onto OC-untreated, $\mathrm{OC}-\mathrm{H}_{2} \mathrm{O}, \mathrm{OC}-\mathrm{HNO}_{3}$, and $\mathrm{OC}-\mathrm{NaOH}$.

\begin{tabular}{|c|c|c|c|c|c|}
\hline Model & Parameters & OC-Untreated & $\mathrm{OC}-\mathrm{H}_{2} \mathrm{O}$ & $\mathrm{OC}-\mathrm{HNO}_{3}$ & $\mathrm{OC}-\mathrm{NaOH}$ \\
\hline \multirow{2}{*}{ Experimental } & $q_{e, \exp }, \mathrm{mg} / \mathrm{g}$ & 34.18 & 26.18 & 14.27 & 42.34 \\
\hline & $q_{e, \text { exp,cor }}, \mathrm{mg} / \mathrm{g}$ & 34.18 & 19.50 & 8.40 & 17.75 \\
\hline \multirow{5}{*}{ Langmuir } & $q_{m}, \mathrm{mg} / \mathrm{g}$ & 36.31 & 26.87 & 13.64 & 47.97 \\
\hline & $q_{m, \text { cor }}, \mathrm{mg} / \mathrm{g}$ & 36.31 & 20.01 & 8.03 & 20.11 \\
\hline & $b, \mathrm{~L} / \mathrm{mg}$ & 0.0366 & 0.134 & 0.117 & 0.0415 \\
\hline & $r^{2}$ & 0.990 & 0.920 & 0.895 & 0.947 \\
\hline & $\sum\left(q_{e e x p}-q_{e c a l}\right)^{2}$ & 6.675 & 29.71 & 6.732 & 56.22 \\
\hline \multirow{4}{*}{ Freundlich } & $\begin{array}{c}K_{F} \\
(\mathrm{mg} / \mathrm{g}) \cdot(\mathrm{L} / \mathrm{mg})^{1 / \mathrm{n}}\end{array}$ & 4.97 & 8.60 & 4.36 & 5.89 \\
\hline & $n$ & 2.87 & 4.69 & 4.76 & 2.63 \\
\hline & $r^{2}$ & 0.972 & 0.917 & 0.964 & 0.860 \\
\hline & $\sum\left(q_{e e x p}-q_{e c a l}\right)^{2}$ & 17.36 & 30.80 & 2.302 & 146.8 \\
\hline \multirow{6}{*}{ Sips } & $q_{m}, \mathrm{mg} / \mathrm{g}$ & 40.74 & 31.19 & 20.29 & 43.44 \\
\hline & $q_{m, c o r}, \mathrm{mg} / \mathrm{g}$ & 40.74 & 23.23 & 11.94 & 18.21 \\
\hline & $b,(\mathrm{~L} / \mathrm{mg})^{1 / \mathrm{n}}$ & 0.0597 & 0.247 & 0.197 & 0.0237 \\
\hline & $n$ & 1.4 & 1.9 & 2.1 & 0.9 \\
\hline & $r^{2}$ & 0.999 & 0.963 & 0.983 & 0.955 \\
\hline & $\sum\left(q_{\text {eexp }}-q_{\text {ecal }}\right)^{2}$ & 0.377 & 13.92 & 1.063 & 47.76 \\
\hline
\end{tabular}

It is noted that the Sips model is the one that best reproduces the experimental results with $r^{2}$ values higher than 0.955. Data of Sips model also showed that the dimensionless $n$ parameter, which qualitatively characterizes the heterogeneity of the sorbate-biosorbent system, seems to strongly depend on treatment agent. For example, $\mathrm{n}$ parameter was 0.9 for $\mathrm{OC}-\mathrm{NaOH}$ material and 2.1 for $\mathrm{OC}-\mathrm{HNO}_{3}$ biosorbent. Similar results were also observed for $b$ parameter, which qualitatively characterizes the biosorption affinity. In this case, $\mathrm{b}$ values ranged from 0.0237 (for OC-NaOH material) to 0.247 (for OC- $\mathrm{H}_{2} \mathrm{O}$ material) $(\mathrm{L} / \mathrm{mg})^{1 / \mathrm{n}}$. It is also detected that the highest $q_{m}$ value was obtained for OC-NaOH. However, if the results of different materials are compared on base of the corrected biosorption capacity, $q_{m, c o r}$ and $q_{e, e x p, c o r}$, the highest biosorption capacity corresponds to the OC-untreated solid. Therefore, 
although treatment with $\mathrm{NaOH}$ increased biosorption capacity, mass loss during treatment did not compensate this enhancement. Similar results were reported by Calero et al. [32] that studied the lead biosorption capacity of olive tree pruning chemically modified by $\mathrm{H}_{2} \mathrm{SO}_{4}, \mathrm{HNO}_{3}$, and $\mathrm{NaOH}$. In the study of Calero et al., the treatment with $\mathrm{NaOH}$ let to obtain values for maximum biosorption capacity about $120 \mathrm{mg} / \mathrm{g}$. However, if loss of mass was taken into account, a maximum biosorption capacity of $66 \mathrm{mg} / \mathrm{g}$ was reached. Either way, in the study of Calero et al. [32], the increase in biosorption performance due to $\mathrm{NaOH}$ treatment compensated the loss of mass of treatment.

On the other hand, in our previous work [14], slow pyrolysis of olive cake was performed under nitrogen atmosphere at different temperatures to obtain carbonaceous materials that were completely characterized and evaluated as adsorbents of cadmium, chromium, copper, nickel, and lead. As an example, a maximum lead adsorption capacity of $102 \mathrm{mg} / \mathrm{g}$ was found for carbonaceous material obtained at $450{ }^{\circ} \mathrm{C}$. It is an adsorption capacity higher than that obtained for hydrolyzed olive cake (prediction of Sips isotherm of $40.74 \mathrm{mg} / \mathrm{g}$ ). However, the cost of slow pyrolysis and the loss of mass due to thermal treatment need to be considered before giving final conclusions about recommendation of making slow pyrolysis better than hydrothermal treatment.

\subsection{Continuous Biosorption Experiments in Fixed-Bed Columns}

In this section, results of biosorption tests performed in fixed-bed columns are reported. Particularly, the corresponding breakthrough curves and their characteristic parameters were obtained. The objective was to determine the influence of the inlet metal concentration, describe the biosorption behavior of the fixed-bed columns, and compare the results with those previously obtained in discontinuous systems by Fernández-González et al. [12].

The breakthrough curves are shown in Figure 5 and their characteristic parameters, calculated according to the equations collected in Table 1, are shown in Table 3.

A change in the inlet metal concentration affected the characteristics of the column. For example, for lead, when the inlet concentration increased from 50 to $200 \mathrm{mg} / \mathrm{L}$, column exhaustion was reached earlier, from 1275 to 565 minutes, respectively. For the highest concentration of metal $(200 \mathrm{mg} / \mathrm{L})$, the exhaustion of the column happened more quickly, reaching 300,375, 565, and 450 minutes for chromium, copper, lead, and zinc, respectively. Also, at low inlet metal concentrations, the volume of solution that could be treated increased. A decrease in the inlet metal concentration caused a delay in the formation of the breakthrough curves and allowed for the treatment of a greater volume of solution, since a lower concentration gradient caused a slower transport due to the decrease of the diffusion coefficient [43].

Table 3. Main characteristic parameters of chromium, copper, lead, and zinc breakthrough curves.

\begin{tabular}{|c|c|c|c|c|c|c|c|c|}
\hline $\begin{array}{l}\text { Heavy } \\
\text { Metal }\end{array}$ & $\begin{array}{l}\text { Inlet Concentration, } \\
\mathrm{mg} / \mathrm{L}\end{array}$ & $\begin{array}{l}t_{\text {total }} \\
\text { min }\end{array}$ & $\begin{array}{r}t_{50} \\
\text { min }\end{array}$ & $\begin{array}{c}q_{\text {total }} \\
\text { mg }\end{array}$ & $\begin{array}{l}m_{\text {total }} \\
\mathrm{mg}\end{array}$ & $\begin{array}{l}V_{e f f r} \\
\mathrm{~mL}\end{array}$ & $\begin{array}{c}q_{e q}, \\
\mathrm{mg} / \mathrm{g}\end{array}$ & $\% R$ \\
\hline \multirow{3}{*}{$\mathrm{Pb}$} & 50 & 1275 & 1005 & 221.41 & 289.02 & 5100 & 12.30 & 77 \\
\hline & 100 & 855 & 585 & 238.04 & 352.12 & 3420 & 13.22 & 68 \\
\hline & 200 & 565 & 255 & 237.86 & 477.76 & 2260 & 13.21 & 50 \\
\hline \multirow{3}{*}{$\mathrm{Cu}$} & 50 & 750 & 410 & 81.09 & 177.00 & 3000 & 4.51 & 46 \\
\hline & 100 & 480 & 160 & 85.31 & 232.32 & 1920 & 4.74 & 37 \\
\hline & 200 & 375 & 105 & 93.02 & 321.00 & 1500 & 5.17 & 30 \\
\hline \multirow{3}{*}{$\mathrm{Cr}$} & 50 & 645 & 190 & 50.86 & 146.03 & 2580 & 2.83 & 35 \\
\hline & 100 & 480 & 100 & 60.76 & 226.18 & 1920 & 3.38 & 27 \\
\hline & 200 & 300 & 40 & 55.44 & 251.04 & 1200 & 3.08 & 22 \\
\hline \multirow{3}{*}{$\mathrm{Zn}$} & 50 & 840 & 375 & 73.79 & 154.56 & 3360 & 4.10 & 48 \\
\hline & 100 & 595 & 195 & 82.37 & 214.20 & 2380 & 4.58 & 38 \\
\hline & 200 & 450 & 95 & 99.18 & 340.20 & 1680 & 5.51 & 29 \\
\hline
\end{tabular}


$\mathrm{Pb}$

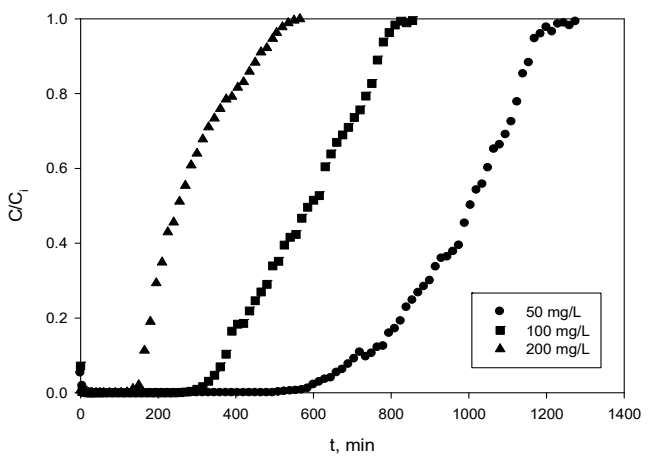

$\mathrm{Cr}$

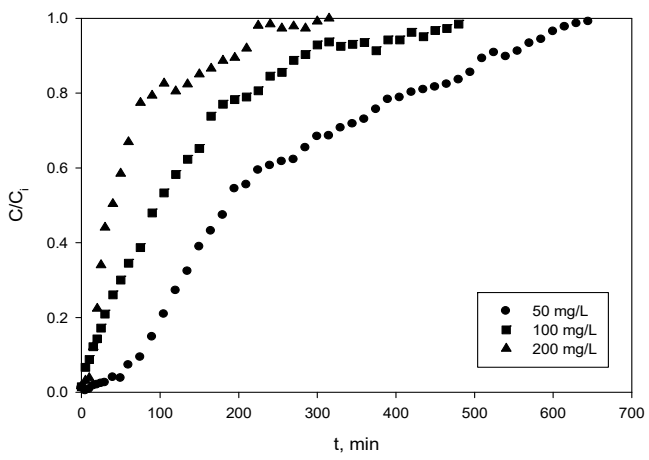

$\mathrm{Cu}$

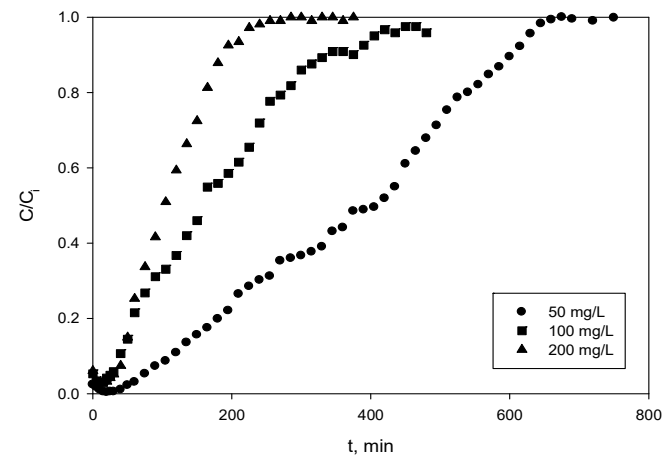

$\mathrm{Zn}$

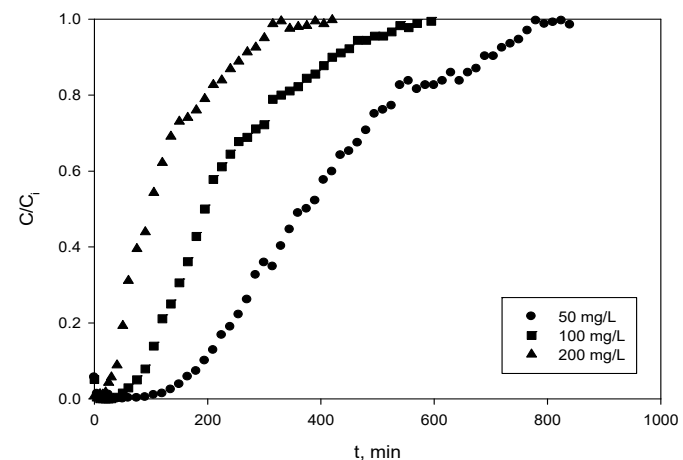

Figure 5. Lead, copper, chromium, and zinc breakthrough curves of OC-untreated at different initial metal concentrations.

Also, in general, the total amount of metal ions adsorbed $\left(q_{t o t a l}\right)$ increased significantly with the increase in the inlet concentration of the metals. Thus, for a concentration of $50 \mathrm{mg} / \mathrm{L}$ of zinc, the $q_{\text {total }}$ reached $73.79 \mathrm{mg}$, while for a concentration of $200 \mathrm{mg} / \mathrm{L}$ of this metal, this amount was $99.18 \mathrm{mg}$.

Likewise, the biosorption capacity, $q_{\text {eq }}$, increased from $2.83 \mathrm{mg} / \mathrm{g}(\mathrm{Cr}), 4.51 \mathrm{mg} / \mathrm{g}(\mathrm{Cu}), 12.30 \mathrm{mg} / \mathrm{g}$ $(\mathrm{Pb})$, and $4.10 \mathrm{mg} / \mathrm{g}(\mathrm{Zn})$ to $3.08 \mathrm{mg} / \mathrm{g}(\mathrm{Cr}), 5.17 \mathrm{mg} / \mathrm{g}(\mathrm{Cu}), 13.21 \mathrm{mg} / \mathrm{g}(\mathrm{Pb})$, and $5.51 \mathrm{mg} / \mathrm{g}(\mathrm{Zn})$ when the concentration of metal ions increased, from $50 \mathrm{mg} / \mathrm{L}$ to $200 \mathrm{mg} / \mathrm{L}$, respectively. However, the percentage of metal removed decreased significantly from $35 \%(\mathrm{Cr}), 46 \%(\mathrm{Cu}), 77 \%(\mathrm{~Pb})$, and $48 \%(\mathrm{Zn})$ to $22 \%$ $(\mathrm{Cr}), 30 \%(\mathrm{Cu}), 50 \%(\mathrm{~Pb})$, and $29 \%(\mathrm{Zn})$ in the same concentration range. On the other hand, values of $q_{e q}$ were lower than those obtained in work of Fernández-González et al. [12] where isotherms of each metal were provided. The authors published maximum biosorption capacities of 22.19, 30.03, 41.54 , and $12.69 \mathrm{mg} / \mathrm{g}$ for $\mathrm{Cr}, \mathrm{Cu}, \mathrm{Pb}$, and $\mathrm{Zn}$ ions, respectively, in batch systems. In general, in terms of biosorption capacity, the worst results were found in continuous flow operation. However, it is important to highlight that results are not provided under similar conditions (i.e., initial concentration). On the other hand, biosorption in fixed-bed column has the benefit that all fluid exiting the column is free from metals up to a certain time. In batch biosorption, the final metal concentration is greater than zero for all initial metal concentrations tested [44].

Next, Thomas, Yoon-Nelson, and dose-response traditional models were used to provide information on biosorption capacity and kinetic coefficients. Table 4 collected the model parameters obtained for each metal initial analyzed. 
Table 4. Thomas, Yoon-Nelson, and dose-response models' parameters for chromium, copper, lead, and zinc breakthrough curves.

\begin{tabular}{|c|c|c|c|c|c|c|c|c|c|c|c|c|c|}
\hline \multirow{2}{*}{ Model } & \multirow{2}{*}{ Parameter } & \multicolumn{3}{|c|}{$\mathrm{Pb}, C_{i} \mathrm{mg} / \mathrm{L}$} & \multicolumn{3}{|c|}{$\mathrm{Cu}, C_{i} \mathrm{mg} / \mathrm{L}$} & \multicolumn{3}{|c|}{$\mathrm{Cr}, C_{i} \mathrm{mg} / \mathrm{L}$} & \multicolumn{3}{|c|}{$\mathrm{Zn}, C_{i} \mathrm{mg} / \mathrm{L}$} \\
\hline & & 50 & 100 & 200 & 50 & 100 & 200 & 50 & 100 & 200 & 50 & 100 & 200 \\
\hline \multirow{4}{*}{$\frac{C}{C_{i}}=\frac{\text { Thomas }}{1+\exp \left(\frac{K_{T h}}{Q}\left(q_{0} m-C_{i} V_{e f f}\right)\right)}$} & 90 & 12.474 & 13.308 & 12.683 & 4.913 & 4.540 & 2.914 & 2.914 & 2.933 & 2.251 & 3.962 & 4.302 & 5.036 \\
\hline & $k_{T h}$ & 0.175 & 0.0990 & 0.0713 & 0.145 & 0.116 & 0.173 & 0.173 & 0.136 & 0.191 & 0.204 & 0.158 & 0.112 \\
\hline & $r^{2}$ & 0.991 & 0.991 & 0.983 & 0.986 & 0.988 & 0.960 & 0.960 & 0.982 & 0.940 & 0.990 & 0.983 & 0.974 \\
\hline & $\sum\left(y-y_{c a l}\right)^{2}$ & 0.0862 & 0.0715 & 0.116 & 0.0992 & 0.0548 & 0.233 & 0.233 & 0.0858 & 0.200 & 0.0879 & 0.108 & 0.132 \\
\hline \multirow{4}{*}{$\begin{array}{c}\text { Yoon-Nelson } \\
\frac{C}{C_{i}}=\frac{1}{1+\exp \left(K_{{ }_{Y N}}(\tau-t)\right)}\end{array}$} & $T$ & 990.6 & 581.7 & 269.9 & 374.7 & 168.8 & 231.7 & 231.7 & 112.1 & 48.4 & 387.6 & 215.1 & 111.9 \\
\hline & $K_{y N}$ & 0.00989 & 0.0102 & 0.0151 & 0.00856 & 0.0140 & 0.0098 & 0.0098 & 0.0159 & 0.0399 & 0.0094 & 0.0142 & 0.0227 \\
\hline & $r^{2}$ & 0.991 & 0.991 & 0.983 & 0.986 & 0.988 & 0.960 & 0.960 & 0.982 & 0.940 & 0.990 & 0.983 & 0.974 \\
\hline & $\sum\left(y-y_{c a l}\right)^{2}$ & 0.0862 & 0.0715 & 0.116 & 0.0992 & 0.0548 & 0.233 & 0.233 & 0.0858 & 0.200 & 0.0879 & 0.108 & 0.132 \\
\hline \multirow{4}{*}{$\begin{array}{l}\text { Dose-Response } \\
\frac{C}{C_{i}}=1-\frac{1}{1+\left(\frac{C_{i} V_{e f}}{q_{0} m}\right)}\end{array}$} & $a$ & 9.732 & 5.714 & 3.919 & 3.053 & 2.147 & 2.042 & 2.042 & 1.606 & 1.633 & 3.518 & 2.886 & 2.247 \\
\hline & $q_{0}$ & 12.395 & 13.047 & 12.114 & 4.594 & 3.920 & 4.683 & 2.487 & 2.272 & 1.968 & 3.760 & 3.965 & 4.338 \\
\hline & $r^{2}$ & 0.986 & 0.947 & 0.994 & 0.962 & 0.983 & 0.992 & 0.992 & 0.987 & 0.990 & 0.996 & 0.997 & 0.995 \\
\hline & $\sum\left(y-y_{c a l}\right)^{2}$ & 0.134 & 0.0969 & 0.0411 & 0.264 & 0.0745 & 0.0440 & 0.0440 & 0.0518 & 0.0311 & 0.0306 & 0.0176 & 0.0242 \\
\hline
\end{tabular}

$K_{T h}$ : Thomas rate constant, $\mathrm{mL} / \mathrm{min} \cdot \mathrm{mg} ; q_{0}$ : maximum concentration of metal in the solid phase, $\mathrm{mg} / \mathrm{g} ; K_{Y N}$ : Yoon-Nelson rate constant, min ${ }^{-1} ; \tau$ : time required to retain $50 \%$ of the inlet metal, min; $a$ : empiric parameter. 
In general, all models showed a successfully correlation with experimental breakthrough curves for all metals and inlet concentrations analyzed. Correlation coefficient values ranged from 0.94 to 0.99. The maximum biosorption capacity, $q_{0}$ constant of Thomas model, fluctuated with the inlet metal concentration and type of metal, ranging from $2.251 \mathrm{mg} / \mathrm{g}$ for an inlet chromium concentration of $200 \mathrm{mg} / \mathrm{L}$ and $13.308 \mathrm{mg} / \mathrm{g}$ for an inlet lead concentration $100 \mathrm{mg} / \mathrm{L}$. These results are similar to those obtained for experimental $q_{e q}$ (Table 3). On the other hand, the values of kinetic constant of Thomas model, $K_{T h}$, had a tendency to decrease as the concentration increased, although this effect was predominantly observed when metal concentration changed from $50 \mathrm{mg} / \mathrm{L}$ to $100 \mathrm{mg} / \mathrm{L}$. The Yoon-Nelson model provided the values of the time required to adsorb the $50 \%$ of the inlet metal, $\tau$. The calculated values were comparable to those obtained experimentally (provided in Table 3), confirming the good fit of this model. In general, a notable decrease of $\tau$ with increasing inlet metal concentration was detected. Finally, the results of the two-parameter empirical model, dose-response model, showed $q_{0}$ values comparable to experimental ones and with $a$ variation with inlet concentrations similar to $q_{0}$ of Thomas model.

\section{Conclusions}

Olive cake was evaluated as biosorbent of heavy metals from aqueous solutions in batch and continuous systems (fixed-bed columns). Results of hydrothermal treatment showed good biosorption properties of the resulting solid material especially when low particle sizes and high temperatures were explored. Results of chemical treatment showed maximum biosorption capacities between $14.27 \mathrm{mg} / \mathrm{g}$ and $42.34 \mathrm{mg} / \mathrm{g}$. Better results were found when hydrolyzed material was submitted to a treatment with $\mathrm{NaOH}$, however, if loss of mass is taken into account, chemical treatment was not interesting. Finally, the experimental data obtained from the biosorption process showed good agreement with the Sips model (batch systems) and Thomas, Yoon-Nelson, and dose-response models (fixed-bed columns systems).

Author Contributions: Conceptualization, R.F.-G., M.Á.M.-L., and M.C.; methodology, R.F.-G., M.Á.M.-L., and M.C.; software, G.B. and A.P.; formal analysis, M.Á.M.-L., G.B., A.P., and M.C.; investigation, R.F.-G.; data curation, R.F.-G.; writing—original draft preparation, M.AÁ.M.-L. and M.C.; writing—review and editing, M.Á.M.-L. and M.C.; supervision, M.Á.M.-L. and M.C.; funding acquisition, M.Á.M.-L., G.B., A.P., and M.C.

Funding: All authors are grateful to the Spanish Ministry of Economy, Industry and Competitiveness for financial support received (Project CTM2016-75977-R).

Conflicts of Interest: The authors declare no conflict of interest.

\section{References}

1. Junta de Andalucía. Production of Olives in Mill Factories in Andalucia. Campaign 2018-2019. 2018. Available online: https://www.juntadeandalucia.es/export/drupaljda/AFORO\%20ACEITUNA\%20ACEITE_ 2018-2019.pdf (accessed on 27 November 2019).

2. Chebaibi, S.; Grandchamp, M.L.; Burgé, G.; Clément, T.; Allais, F.; Laziri, F. Improvement of protein content and decrease of anti-nutritional factors in olive cake by solid-state fermentation: A way to valorize this industrial by-product in animal feed. J. Biosci. Bioeng. 2019, 128, 384-390. [CrossRef]

3. Dorbane, Z.; Kadi, S.A.; Boudouma, D.; Gater-Belaid, N.; Bannelier, C.; Berchiche, M.; Gidenne, T. Nutritive value of two types of olive cake (Olea europaea L.) for growing rabbit. World Rabbit Sci. 2019, 27, 69-75. [CrossRef]

4. Ferrer, P.; García-Rebollar, P.; Cerisuelo, A.; Ibáñez, M.A.; Rodríguez, C.A.; Calvet, S.; De Blas, C. Nutritional value of crude and partially defatted olive cake in finishing pigs and effects on nitrogen balance and gaseous emissions. Anim. Feed Sci. Technol. 2018, 236, 131-140. [CrossRef]

5. Marcos, C.N.; García-Rebollar, P.; de Blas, C.; Carro, M.D. Variability in the chemical composition and in vitro ruminal fermentation of olive cake by-products. Animals 2019, 9, 109. [CrossRef] [PubMed]

6. Symeou, S.; Tsiafoulis, C.G.; Gerothanassis, I.P.; Miltiadou, D.; Tzamaloukas, O. Nuclear magnetic resonance screening of changes in fatty acid and cholesterol content of ovine milk induced by ensiled olive cake inclusion in Chios sheep diets. Small Ruminant Res. 2019, 177, 111-116. [CrossRef] 
7. Pasten, A.; Uribe, E.; Stucken, K.; Rodríguez, A.; Vega-Gálvez, A. Influence of Drying on the Recoverable High-Value Products from Olive (cv. Arbequina) Waste Cake. Waste Biomass Valoriz. 2019, 10, 1627-1638. [CrossRef]

8. Khalili, F.; Dinani, S.T. Extraction of phenolic compounds from olive-waste cake using ultrasonic process. J. Food Meas. Charact. 2018, 12, 974-981. [CrossRef]

9. Mojerlou, Z.; Elhamirad, A. Optimization of ultrasound-assisted extraction (UAE) of phenolic compounds from olive cake. Int. J. Food Sci. Technol. 2018, 55, 977-984. [CrossRef]

10. Sandouqa, A.; Al-Hamamre, Z.; Asfar, J. Preparation and performance investigation of a lignin-based solid acid catalyst manufactured from olive cake for biodiesel production. Renew. Energy 2019, 132, 667-682. [CrossRef]

11. Delgado-Moreno, L.; Bazhari, S.; Nogales, R.; Romero, E. Innovative application of biobed bioremediation systems to remove emerging contaminants: Adsorption, degradation and bioaccesibility. Sci. Total Environ. 2019, 651, 990-997. [CrossRef]

12. Fernández-González, R.; Martín-Lara, M.A.; Iáñez-Rodríguez, I.; Calero, M. Removal of heavy metals from acid mining effluents by hydrolyzed olive cake. Bioresour. Technol. 2018, 268, 169-175. [CrossRef] [PubMed]

13. Fernández-González, R.; Martín-Lara, M.A.; Moreno, J.A.; Blázquez, G.; Calero, M. Effective removal of zinc from industrial plating wastewater using hydrolyzed olive cake: Scale-up and preparation of zinc-Based biochar. J. Clean. Prod. 2019, 227, 634-644. [CrossRef]

14. Martín-Lara, M.A.; Pérez, A.; Vico-Pérez, M.A.; Calero, M.; Blázquez, G. The role of temperature on slow pyrolysis of olive cake for the production of solid fuels and adsorbents. Process Saf. Environ. Protect. 2019, 121, 209-220. [CrossRef]

15. Toumi, K.-H.; Benguerba, Y.; Erto, A.; Dotto, G.L.; Khalfaoui, M.; Tiar, C.; Nacef, S.; Amrane, A. Molecular modeling of cationic dyes adsorption on agricultural Algerian olive cake waste. J. Mol. Liq. 2018, 264, 127-133. [CrossRef]

16. Toumi, K.-H.; Benguerba, Y.; Erto, A.; Dotto, G.L.; Tiar, C.; Nacef, S.; Amrane, A.; Ernst, B. Efficient Removal of Cationic Dyes From Aqueous Solutions Using the Low-Cost Algerian Olive Cake Waste Adsorbent. JOM 2019, 71, 791-800. [CrossRef]

17. Castro, L.; Blázquez, L.; González, F.; Muñoz, J.A.; Ballester, A. Biosorption of Zn(II) fromindustrial effluents using sugar beet pulp and F. vesiculosus: From laboratory tests to a pilot approach. Sci. Total Environ. 2017, 598, 856-866. [CrossRef]

18. Castro, L.; Bonilla, L.A.; González, F.; Ballester, A.; Blázquez, M.L.; Muñoz, J.A. Continuous metal biosorption applied to industrial effluents: A comparative study using an agricultural by-product and a marine alga. Environ. Earth Sci. 2017, 76, 491. [CrossRef]

19. Akar, S.; Lorestani, B.; Sobhanardakani, S.; Cheraghi, M.; Moradi, O. Surveying the efficiency of Platanus orientalis bark as biosorbent for $\mathrm{Ni}$ and $\mathrm{Cr}(\mathrm{VI})$ removal from plating wastewater as a real sample. Environ. Monit. Assess. 2019, 191, 373. [CrossRef]

20. Bulgariu, L.; Bulgariu, D. Functionalized soy waste biomass-A novel environmental-friendly biosorbent for the removal of heavy metals from aqueous solution. J. Clean. Prod. 2018, 197, 875-885. [CrossRef]

21. Loiacono, S.; Crini, G.; Chanet, G.; Raschetti, M.; Placet, V.; Morin-Crini, N. Metals in aqueous solutions and real effluents: Biosorption behavior of a hemp-based felt. J. Chem. Technol. Biotechnol. 2018, 93, 2592-2601. [CrossRef]

22. Mazur, L.P.; Cechinel, M.A.P.; de Souza, S.M.A.G.U.; Boaventura, R.A.R.; Vilar, V.J.P. Brown marine macroalgae as natural cation exchangers for toxic metal removal from industrial wastewaters: A review. J. Environ. Manag. 2018, 223, 215-253. [CrossRef] [PubMed]

23. Beni, A.A.; Esmaeili, A. Biosorption, an efficient method for removing heavy metals from industrial effluents: A Review. Environ. Technol. Innov. 2020, 17, 100503. [CrossRef]

24. Araújo, D.; Vilarinho, M.; Machado, A. Effect of combined dilute-alkaline and green pretreatments on corncob fractionation: Pretreated biomass characterization and regenerated cellulose film production. Ind. Crop. Prod. 2019, 141, 111785. [CrossRef]

25. Choi, J.-H.; Park, S.-Y.; Kim, J.-H.; Cho, S.-M.; Jang, S.-K.; Hong, C.; Choi, I.-G. Selective deconstruction of hemicellulose and lignin with producing derivatives by sequential pretreatment process for biorefining concept. Bioresour. Technol. 2019, 291, 121913. [CrossRef] [PubMed] 
26. Chu, Q.; Song, K.; Hu, J.; Bu, Q.; Zhang, X.; Chen, X. Integrated process for the coproduction of fermentable sugars and lignin adsorbents from hardwood. Bioresour. Technol. 2019, 289, 121659. [CrossRef] [PubMed]

27. Gálvez-Pérez, A.; Pérez, A.; Calero, M.; Martín-Lara, M.A.; Blázquez, G. Integral exploitation from olive cake for energy production in a biorefinery scheme. Process Saf. Environ. Protect. 2019, 131, 135-143. [CrossRef]

28. Manzanares, P.; Ballesteros, I.; Negro, M.J.; González, A.; Oliva, J.M.; Ballesteros, M. Processing of extracted olive oil pomace residue by hydrothermal or dilute acid pretreatment and enzymatic hydrolysis in a biorefinery context. Renew. Energy 2020, 145, 1235-1245. [CrossRef]

29. Hrnčič, M.K.; Kravanja, G. Knez, Ž. Hydrothermal treatment of biomass for energy and chemicals. Energy 2016, 116, 1312-1322. [CrossRef]

30. Blázquez, G.; Calero, M.; Hernainz, F.; Tenorio, G.; Martín-Lara, M.A. Equilibrium biosorption of lead(II) from aqueous solutions by solid waste from olive-oil production. Chem. Eng. J. 2010, 160, 615-622. [CrossRef]

31. Blázquez, G.; Calero, M.; Ronda, A.; Tenorio, G.; Martín-Lara, M.A. Study of kinetics in the biosorption of lead onto native and chemically treated olive stone. J. Ind. Eng. Chem. 2014, 20, 2754-2760. [CrossRef]

32. Calero, M.; Ronda, A.; Martín-Lara, M.A.; Pérez, A.; Blázquez, G. Chemical activation of olive tree pruning to remove lead(II) in batch system: Factorial design for process optimization. Biomass Bioenerg. 2013, 58, 322-332. [CrossRef]

33. Martín-Lara, M.A.; Rodríguez, I.L.; Blázquez, G.; Calero, M. Factorial experimental design for optimizating the removal conditions of lead ions from aqueous solutions by three wastes of the olive-oil production. Desalination 2011, 278, 132-140. [CrossRef]

34. Martín-Lara, M.A.; Blázquez, G.; Calero, M.; Almendros, A.I.; Ronda, A. Binary biosorption of copper and lead onto pine cone Shell in batch reactors and in fixed bed columns. Int. J. Miner. Process. 2016, 148, 72-82. [CrossRef]

35. Ronda, A.; Martín-Lara, M.A.; Almendros, A.I.; Pérez, A.; Blázquez, G. Comparison of two models for the biosorption of $\mathrm{Pb}(\mathrm{II})$ using untreated and chemically treated olive stone: Experimental design methodology and adaptive neural fuzzy inference system (ANFIS). J. Taiwan Inst. Chem. Eng. 2015, 54, 45-56. [CrossRef]

36. Langmuir, I. The adsorption of gases on plane surfaces of glass, mica and platinum. J. Am. Chem. Soc. 1918, 40, 1361-1403. [CrossRef]

37. Freundlich, H.M.F. Over the Adsorption in Solution. J. Phys. Chem. 1906, 57, 385-471.

38. Sips, R. Structure of a catalyst surface. J. Chem. Phys. 1948, 16, 490-495. [CrossRef]

39. Akpomie, K.G.; Dawodu, F.A.; Adebowale, K.O. Mechanism on the sorption of heavy metals from binary-solution by a low cost montmorillonite and its desorption potential. Alex. Eng. J. 2015, 54, 757-767. [CrossRef]

40. González-Bermúdez, Y.; Rodríguez-Rico, I.L.; Guibal, E.; Calero, M.; Martín-Lara, M.A. Biosorption of hexavalent chromium from aqueous solution by Sargassum muticum brown alga. Application of statistical design for process optimization. Chem. Eng. J. 2012, 183, 68-76. [CrossRef]

41. Pimol, P.; Khanidtha, M.; Prasert, P. Influence of particle size and salinity on adsorption of basic dyes by agricultural waste: Dried Seagrape (Caulerpa lentillifera). J. Environ. Sci. 2008, 20, 760-768. [CrossRef]

42. Hernáinz, F.; Blázquez, G.; Calero, M.; Martín-Lara, M.A. Influence of some parameters on lead biosorption by agricultural waste. Afinidad 2008, 65, 286-292.

43. Padmesh, T.V.N.; Vijayaraghavan, K.; Sekaran, G.; Velan, M. Batch and column studies on biosorption of acid dyes on fresh water macro alga Azolla filiculoides. J. Hazard. Mater. 2005, 125, 121-129. [CrossRef] [PubMed]

44. Dichiara, A.B.; Wainstein, S.J.; Rogers, R.E. On the choice of batch or fixed bed adsorption processes for wastewater treatment. Ind. Eng. Chem. Res. 2015, 54, 8579-8586. [CrossRef]

(C) 2019 by the authors. Licensee MDPI, Basel, Switzerland. This article is an open access article distributed under the terms and conditions of the Creative Commons Attribution (CC BY) license (http://creativecommons.org/licenses/by/4.0/). 